\title{
Slow-release urea in diets for lactating crossbred cows
}

\section{Bruno Tadeu Santiago', Severino Delmar Junqueira Villela', Fernando de Paula Leonel ${ }^{2}$, Joanis Tilemahos Zervoudakis ${ }^{3}$, Raphael Pavesi Araújo ${ }^{4}$, Henrique Valentim Nunes Machado², Leonardo Marmo Moreira ${ }^{2}$, Tadeu Silva de Oliveira ${ }^{5}$}

\author{
${ }^{1}$ Universidade Federal dos Vales do Jequitinhonha e Mucuri, Departamento de Zootecnia, Diamantina, MG, Brasil. \\ ${ }^{2}$ Universidade Federal de São João del Rei, Departamento de Zootecnia, São João del Rei, MG, Brasil. \\ ${ }^{3}$ Universidade Federal de Mato Grosso, Faculdade de Agronomia, Medicina Veterinária e Zootecnia, Cuiabá, MT, Brasil. \\ ${ }^{4}$ Instituto Federal do Tocantins, Colinas do Tocantins, TO, Brasil. \\ ${ }^{5}$ Universidade Estadual do Norte Fluminense Darcy Ribeiro, Departamento de Nutrição Animal, Campos dos Goytacazes, RJ, Brasil.
}

\begin{abstract}
The objective of this study was to evaluate the performance of F1 (Holstein $\times$ Zebu) cows in lactation according to different levels of substitution of soybean meal for a protein equivalent non-protein nitrogen originated from slow-release urea (SRU). Eight F1 (Holstein $\times$ Zebu) cows in the first third of lactation, with an average milk yield of $12.7 \mathrm{~kg}$ $( \pm 3.1 \mathrm{~kg}) /$ day and a live weight of $552 \mathrm{~kg}( \pm 30 \mathrm{~kg})$, were used. The experimental design was composed of two simultaneous $4 \times 4$ Latin squares, with the following treatments: $100 \%$ soybean meal and $0 \%$ SRU; $66 \%$ soybean meal and $34 \%$ SRU; $34 \%$ soybean meal and $66 \%$ SRU; and $0 \%$ soybean meal and 100\% SRU. Sorghum silage, used as roughage, was supplied together with the concentrate. Feed intake and digestibility as well as milk yield and milk composition were measured. The obtained data were subjected to analysis of variance, adopting a $5 \%$ probability level. No intake variable showed significant differences among the treatments, and the mean values for the intakes of dry matter (DM), crude protein (CP) and neutral detergent fiber (NDF) were 18.352 .62 and $5.85 \mathrm{~kg}$ /day, respectively. The results for apparent digestibility also did not show differences among treatments, with DM, CP and NDF averaging 58.16, 58.64 and 36.21\%, respectively. Milk yield and composition were similar among the treatments. The average 4\%-fat-corrected milk yield was $13.39 \mathrm{~kg} /$ animal.day. Intake, digestibility and milk yield and composition variables are not changed according to the substitution of the soy protein for slow-release urea. Thus, for average-milk-yield crossbred animals, this substitution depends on economic variables only.
\end{abstract}

Key Words: digestibility, intake, milk composition, soybean meal

\section{Introduction}

In Brazil, one of the most largely used protein sources in the formulation of diets for lactating cows is soybean meal. However, due to the high market prices of this ingredient in recent years and the competitiveness with other animal species for this food source, livestock farmers have chosen to use non-protein nitrogen (NPN) in animal diets as a way to reduce costs. Urea is the most common source of NPN utilized in ruminant feeding due to its low cost and high protein equivalent.

One of the biggest problems concerning the use of urea is its rapid hydrolysis in the rumen, caused by the activity of ureases secreted from ruminal microorganisms. This rapid hydrolysis may result in ammonia $\mathrm{N}$ being available in the rumen at a higher rate than the capacity of microbial protein synthesis, which would result in excessive loss of $\mathrm{N}$

Received October 11, 2014 and accepted March 17, 2015.

Corresponding author: fernandoleonel@ufsj.edu.br

http://dx.doi.org/10.1590/S1806-92902015000500005

Copyright (C) 2015 Sociedade Brasileira de Zootecnia. This is an Open Access article distributed under the terms of the Creative Commons Attribution Non-Commercial License, which permits unrestricted non-commercial use, distribution, and reproduction in any medium, provided the original work is properly cited.
(Lapierre and Lobley, 2001). In order to optimize microbialprotein production, there must be a synchrony between the availability of energy and nitrogen compounds in the rumen environment (Russel et al., 1992; Firkins, 1996).

That being, some products have been released in the market in the last few years based on the coating of urea, aiming to slow its release rate within the rumen in order to reach a better synchrony with the carbohydrate fermentation rate and improve microbial efficiency. The urea physically encapsulated by vegetable waxes is aimed at reducing the speed of ammonia release into the rumen (Santos et al., 2011). This type of urea has been tested in some experiments with dairy cows (Galo et al., 2003; Akay et al., 2004; Souza et al., 2010; Santos et al., 2011; Sinclair et al., 2012). However, the efficiency of this product must be evaluated in diets for crossbred cows with average milk yield. The evaluation of this type of product in production systems that utilize crossbred animals is interesting, since it will represent the Brazilian herd, as most of the cattle intended for milk production in Brazil are from crosses between taurine and zebu breeds.

Thus, the objective of this study was to evaluate the partial and total substitution of soybean meal for slow- 
release urea (SRU) in diets for F1 (Holstein $\times$ Zebu) cows of average daily milk yield and its effect on production and composition of their milk, as well as on the intake and digestibility of the diets.

\section{Material and Methods}

The experiment was conducted in a location with the following coordinates, $21^{\circ} 08^{\prime} 00^{\prime \prime} \mathrm{S}$ latitude and $44^{\circ} 15^{\prime} 40^{\prime \prime} \mathrm{W}$ longitude, at an altitude of $898 \mathrm{~m}$. Eight F1 (Holstein $\times$ Zebu) crossbred cows in the initial third of lactation at the beginning of the experimental period, with a milk yield of $12.7 \mathrm{~kg}( \pm 3.1 \mathrm{~kg}) /$ day and a live weight of $552 \mathrm{~kg}( \pm 30 \mathrm{~kg})$ were used. The animals were allocated to individual stalls provided with automatic drinkers and individual feeders. The stalls had cement floor and were partially covered with clay tiles. Cows remained confined from the start to the end of the experiment, and were withdrawn only for milking, which occurred twice daily.

Table 1 - Composition of the concentrates supplied in the experimental diets, expressed as percentage of the ingredients used in their formulation

\begin{tabular}{lcccc}
\hline \multirow{2}{*}{ Ingredients } & \multicolumn{4}{c}{ Treatments $^{1}$} \\
\cline { 2 - 5 } & Control & 34SRU & 66SRU & 100SRU \\
\hline Corn $(\mathrm{g} / \mathrm{kg})$ & 557.5 & 668.5 & 772.7 & 883.7 \\
Soybean meal $(\mathrm{g} / \mathrm{kg})$ & 400.0 & 264.0 & 136 & - \\
Urea $(\mathrm{g} / \mathrm{kg})$ & 10 & 10 & 10 & 10 \\
Calcium sulfate $(\mathrm{g} / \mathrm{kg})$ & 2.5 & 7.5 & 12.3 & 17.3 \\
Slow-release urea $(\mathrm{g} / \mathrm{kg})$ & - & 20 & 39 & 59 \\
Mineral mix ${ }^{2}(\mathrm{~g} / \mathrm{kg})$ & 30 & 30 & 30 & 30 \\
Total $(\mathrm{g} / \mathrm{kg})$ & 1000 & 1000 & 1000 & 1000 \\
\hline
\end{tabular}

${ }^{1}$ Treatments: control - $100 \%$ soybean meal and $0 \%$ slow-release urea; 34 SRU - $66 \%$ soybean meal and 34\% slow-release urea; 66SRU - 34\% soybean meal and $66 \%$ slow-release urea; 100SRU - $0 \%$ soybean meal and 100\% slow-release urea.

${ }^{2}$ Guaranteed levels per kg of product: calcium (max.) $205 \mathrm{~g}$; calcium (min.) $195 \mathrm{~g}$; phosphorus (min.) $100 \mathrm{~g}$; sodium (min.) $68 \mathrm{~g}$; sulfur (min.) $12 \mathrm{~g}$; magnesium (min.) $15 \mathrm{~g}$; cobalt (min.) $200 \mathrm{mg}$; copper (min.) 1,650 mg; iodine (min.) $195 \mathrm{mg}$; manganese (min.) 1,960 mg; selenium (min.) $32 \mathrm{mg}$; zinc (min.) 6,285 mg; iron (min.) $560 \mathrm{mg}$; fluorine (min.) 1,000 mg.
The experimental design was composed of two simultaneous $4 \times 4$ Latin squares, with four treatments and four animals. The experimental periods lasted 15 days each, with the first 12 days used for adaptation of animals to the diet, and the last three for sample collection.

In the treatments, levels of substitution of soybean meal for Optigen ${ }^{\circledR}$ II (Alltech Inc., Nicholasville, USA), a slowdegradation coated urea, were tested as sources of protein in the concentrate. The treatments (Table 1) were: $100 \%$ soybean meal and 0\% SRU (Control); 66\% soybean meal and $34 \%$ SRU; $34 \%$ soybean meal and $66 \%$ SRU; and $0 \%$ soybean meal and $100 \%$ SRU.

A total diet composed of concentrate mixed with the sorghum silage, with a roughage:concentrate ratio of $75: 25$, was supplied daily and individually in the trough. The diets were formulated (Table 2) to be isoproteic, following NRC (2001) recommendations, according to the production level, weight, calving order, and lactation stage. Forty kilograms of sorghum silage were supplied twice daily in each animal, at $07.00 \mathrm{~h}$ and $15.00 \mathrm{~h}$, immediately after milking.

Samples of total diet and orts from the trough were collected and frozen during the three days of collection in each period, forming a composite sample, which was subsequently pre-dried for the analyses. The samples were dried in a forced-ventilation oven set at $55^{\circ} \mathrm{C}$ for $72 \mathrm{~h}$, and the definitive dry matter was determined in an oven at $105^{\circ} \mathrm{C}$ (DM, method 967.03; AOAC, 1998), Crude protein (CP, method 2001.11; Thiex et al., 2002) without corrections for nitrogen losses during digestion and distillation phases as well as the use of $100 \mathrm{~mL}$ test tubes, crude fat $(\mathrm{CF}$, method 2,003.06; Thiex et al., 2003), ash (method 942.05; AOAC, 1998), and lignin (H2SO4 72\% p/p) were analyzed according to the techniques described by method 973.18 of the AOAC (1998). The neutral detergent fiber was evaluated according to the protocols suggested by Goering

Table 2 - Chemical composition of the total diets supplied in each experimental treatment

\begin{tabular}{|c|c|c|c|c|c|}
\hline \multirow{2}{*}{ Variable } & \multirow{2}{*}{ Sorghum silage } & \multicolumn{4}{|c|}{ Total diet } \\
\hline & & Control & 34SRU & 66SRU & 100SRU \\
\hline Dry matter $(\mathrm{g} / \mathrm{kg})^{1}$ & 345.7 & 442.6 & 452.5 & 446.0 & 452.2 \\
\hline Organic matter $(\mathrm{g} / \mathrm{kg})^{2}$ & 929.7 & 931.2 & 934.2 & 929.4 & 933.2 \\
\hline Crude protein $(\mathrm{g} / \mathrm{kg})^{2}$ & 52.2 & 131.2 & 136.6 & 133.9 & 143.7 \\
\hline Ether extract $(\mathrm{g} / \mathrm{kg})^{2}$ & 24.7 & 24.0 & 27.0 & 26.4 & 28.1 \\
\hline Total carbohydrates $(\mathrm{g} / \mathrm{kg})^{2}$ & 852.8 & 776.0 & 770.6 & 769.1 & 761.4 \\
\hline Neutral detergent fiber $(\mathrm{g} / \mathrm{kg})^{2}$ & 481.1 & 346.8 & 326.0 & 354.8 & 338.8 \\
\hline Acid detergent fiber $(\mathrm{g} / \mathrm{kg})^{2}$ & 236.3 & 165.2 & 158.9 & 165.6 & 151.4 \\
\hline $\operatorname{Lignin}(\mathrm{g} / \mathrm{kg})^{2}$ & 45.1 & 39.1 & 37.9 & 44.2 & 39.5 \\
\hline Mineral matter $(\mathrm{g} / \mathrm{kg})^{2}$ & 70.3 & 68.8 & 65.8 & 70.6 & 66.8 \\
\hline Total digestible nutrients $(\mathrm{g} / \mathrm{kg})^{3}$ & 550.0 & 625.8 & 617.7 & 610.5 & 602.7 \\
\hline
\end{tabular}

Treatments: Control - 100\% soybean meal and 0\% slow-release urea; 34SRU - 66\% soybean meal and 34\% slow-release urea; 66 SRU - 34\% soybean meal and 66\% slow-release urea; 100 SRU - $0 \%$ soybean meal and $100 \%$ slow-release urea.

${ }^{1}$ Expressed as a percentage of the natural matter (as is).

${ }^{2}$ Expressed as a percentage of the dry matter.

${ }^{3}$ Estimated based on the individual ingredients in accordance with Weiss et al. (1992). 
and Van Soest (1970) as follows: $1.0 \mathrm{~g}$ of each sample and $100 \mathrm{~mL}$ of a neutral detergent solution (without $\mathrm{Na}_{2} \mathrm{SO}_{3}$ and no addition of heat-stable amylase) were transferred to $600 \mathrm{~mL}$ glass recipients and this solution remained in boiling point for $60 \mathrm{~min}\left(100^{\circ} \mathrm{C}\right)$. Subsequently, the content was filtered in a crucible with coarse porosity. After transfer, $20 \mathrm{~mL}$ of acetone were added to each crucible and vacuum applied. Subsequently, $20 \mathrm{~mL}$ of boiling water were added. The glass crucibles were disposed for oven drying at $105^{\circ} \mathrm{C}$ for eight hours until constant weights were achieved. In the final step of this procedure, residual contents in crucibles were ashed at $470{ }^{\circ} \mathrm{C}$ for four hours and final weights recorded to determine the fibrous organic matter.

To estimate the organic matter (OM) content, mineral matter was subtracted from the dry matter.

The dry matter intake (DMI) was determined as the difference between the amount of feed (kilograms of dry matter) supplied to the animal and the amount of orts (kilograms of dry matter) collected from the trough, according to the equation: DMI $(\mathrm{kg} /$ day $)=$ amount supplied (kg DM) - amount of orts ( $\mathrm{kg} \mathrm{DM})$.

The DMI as percentage of body weight (DMIBW) was calculated by the equation: DMIBW $(\% \mathrm{BW})=(\mathrm{DMI} / \mathrm{BW})$ $\times 100$. The DMI as a function of the metabolic weight was also calculated, using following equation: DMIMW $(\mathrm{g} / \mathrm{kg}$ $\left.\mathrm{BW}^{0.75}\right)=\mathrm{g}$ DM consumed $/ \mathrm{BW}^{0.75}$.

The live weight of the animals was measured by weighing the cows at the end of each experimental period, which would happen always after the morning milking. Metabolic weight (MW) was obtained as a function of the body weight $\left(\mathrm{MW}=\mathrm{BW}^{0.75}\right)$.

The intakes of CP and NDF were estimated similarly to the dry matter intake.

Feed efficiency $(\mathrm{FE}=\mathrm{kg}$ milk $/ \mathrm{kg} \mathrm{DMI})$ and feed conversion $(\mathrm{FC}=\mathrm{DMI} /$ milk yield) were calculated.

For the estimate of the digestibility of the diets, chromic oxide was utilized as an external marker, in the form of capsules coated with filter paper at the amount of $10 \mathrm{~g} /$ animal. day, supplied in a single dose, after the morning milking. The marker was introduced daily into the esophagus of the animals using an applicator, according to Silva and Leão (1979). This procedure was performed in the entire experimental period, in order to estimate the daily fecal output.

Samples of feces were collected twice daily, after the milkings, during the three days for collection of each period, forming a composite sample for the analyses. To obtain the pre-dried matter, samples were conditioned in paper bags, dried in a forced-ventilation oven at $65^{\circ} \mathrm{C}$ for $72 \mathrm{~h}$, and then ground in a $1 \mathrm{~mm}$-sieve Thomas Wiley mill. Subsequently, the samples were subjected to analysis by
Atomic Absorption Spectrometry (AAS) according to the methodology proposed by Williams et al. (1962). With the results obtained by readings with the spectrometer, the chromic oxide concentration in the feces was determined (COF, g/g DM). Next, fecal production (FP) was calculated based on the amount of chromic oxide supplied (COS, g/day), using the following equation: $\mathrm{FP}(\mathrm{g} \mathrm{DM} /$ day $)=\mathrm{COS} / \mathrm{COF}$.

Based on the fecal output and dry matter intake data, the apparent digestibility of dry matter (ADDM) was estimated with the equation: $\operatorname{ADDM}(\%)=(\mathrm{DMI}-\mathrm{FP} / \mathrm{DMI}) \times 100$.

Samples of feces were also analyzed for the dry matter (DM, method 967.03; AOAC, 1998), crude protein (CP, method 2001.11; Thiex et al., 2002), and neutral detergent fiber (NDF) (Van Soest, 1963) contents.

To measure milk yield, weighing was performed in the mornings and afternoons of the days of sample collection. To evaluate the milk composition (fat, protein, total solids, and solids nonfat), one sample proportional to the productions in the morning and another in the afternoon were collected in these periods to form a composite sample. Next, these samples were stored in bottles containing Bromopol ${ }^{\circledR}$ specific for milk physicochemical analyses, and immediately conditioned in a Styrofoam box containing reusable ice packs. Data pertaining to the milk fat content were utilized to standardize milk yield for $4 \%$ fat ( $4 \% \mathrm{FCMY})$, following the methodology proposed by Sklan et al. (1992).

Because the variable ADDM was obtained for the division between variable with normal distribution, it follows the Cauchy distribution (Mood et al., 1974); therefore, this variable was transformed according to the descriptions of Box and Cox (1964).

The following linear mixed statistical model was adopted (Tempelman, 2004):

$$
Y_{i k l}=\mu+\alpha_{i}+c_{k}+\beta_{l}+\alpha \beta_{i l}+e_{i k l},
$$

in which $Y_{i k l}$ is the observation related to the variable measured in the $k$-th cow fed the $i$-th treatments during the $l$-th period. The fixed effects are the mean $(\mu)$, the treatments $\left(\alpha_{i}\right)$, the periods for the two simultaneous balanced Latin squares $\left(\beta_{l}\right)$, and the treatment $\times$ period interaction $\left(\alpha \beta_{i l}\right)$. The random effects are cow $\left(c_{k}\right)$ and the usual error term $\left(e_{i k l}\right)$.

The statistical model was fitted using the PROC MIXED procedure of SAS (Statistical Analysis System, version 9) with restricted maximum likelihood (REML) as the estimation method. The repeated command was used with $c_{k}$ as subjects. The comparison between treatments was done by the F test, and subsequently to a regression analysis for the variables that showed significant effect at $5 \%$ probability. 


\section{Results}

The intakes of DM, CP and NDF, according to the evaluated diets, were not affected $(\mathrm{P}>0.05)$ with substitution of soybean meal for slow-release urea, and the overall mean values for these three respective variables were 18.35, 2.62, and $5.85 \mathrm{~kg} /$ day, respectively (Table 3 ).

The intakes of CP, DM, and NDF were also measured as a function of the body weight (BW) and of the metabolic weight $\left(\mathrm{BW}^{0.75}\right)$. The mean values for the intakes of the three respective variables as a function of the body weight and metabolic weight were $3.39 \%$ and $163.61 \mathrm{~g} / \mathrm{kg} \mathrm{BW}^{0.75} ; 0.48 \%$ and $23.35 \mathrm{~g} / \mathrm{kg} \mathrm{BW}^{0.75}$; and $1.08 \%$ and $52.19 \mathrm{~g} / \mathrm{kg} \mathrm{BW}^{0.75}$, and no differences were found $(\mathrm{P}>0.05)$.

Regarding the feed efficiency and feed conversion, the results did not differ $(\mathrm{P}>0.05)$ (Table 3$)$. The average feed efficiency was $0.72 \mathrm{~kg}$ milk/kg DMI, and the average feed conversion was $1.44 \mathrm{DMI} / \mathrm{kg}$ milk.

The mean values for the apparent digestibility of DM, $\mathrm{CP}$ and NDF of the diets were similar $(\mathrm{P}>0.05)$ (Table 4). The overall mean apparent digestibility values of DM, CP, and NDF were $58.16,58.64$, and $36.21 \%$, respectively.

There was also no effect $(\mathrm{P}>0.05)$ of diets on $4 \%$ fat-corrected milk yield and percentages of fat, protein,

Table 3 - Mean values for intakes of dry matter, crude protein and neutral detergent fiber (in kg/day and as a function of body weight and metabolic weight), feed efficiency, and feed intake according to each treatment

\begin{tabular}{|c|c|c|c|c|c|c|}
\hline \multirow{2}{*}{ Variable } & \multicolumn{4}{|c|}{ Treatments $^{1}$} & \multirow{2}{*}{ CV $(\%)$} & \multirow{2}{*}{ P-value } \\
\hline & Control & 34SRU & 66SRU & 100SRU & & \\
\hline \multicolumn{7}{|l|}{ Dry matter intake } \\
\hline $\mathrm{kg} /$ day & 18.20 & 18.44 & 18.76 & 17.99 & 6.898 & 0.555 \\
\hline$\% \mathrm{BW}$ & 3.34 & 3.42 & 3.44 & 3.37 & 8.664 & 0.208 \\
\hline $\mathrm{g} / \mathrm{kg} \mathrm{BW}^{0.75}$ & 161.20 & 164.75 & 166.35 & 162.14 & 8.095 & 0.255 \\
\hline \multicolumn{7}{|l|}{ Crude protein intake } \\
\hline $\mathrm{kg} /$ day & 2.50 & 2.65 & 2.62 & 2.70 & 11.207 & 0.678 \\
\hline$\% \mathrm{BW}$ & 0.46 & 0.50 & 0.48 & 0.51 & 12.694 & 0.903 \\
\hline $\mathrm{g} / \mathrm{kg} \mathrm{BW}^{0.75}$ & 22.10 & 23.76 & 23.21 & 24.35 & 12.432 & 0.871 \\
\hline \multicolumn{7}{|l|}{ Neutral detergent fiber intake } \\
\hline $\mathrm{kg} /$ day & 5.92 & 5.59 & 6.29 & 5.63 & 13.216 & 1.408 \\
\hline$\% \mathrm{BW}$ & 1.08 & 1.04 & 1.15 & 1.06 & 13.501 & 0.934 \\
\hline $\mathrm{g} / \mathrm{kg} \mathrm{BW} W^{0.75}$ & 52.31 & 49.96 & 55.64 & 50.85 & 13.338 & 1.028 \\
\hline Feed efficiency (kg milk/kg DMI) & 0.74 & 0.77 & 0.72 & 0.66 & 11.525 & 0.128 \\
\hline Feed conversion ( $\mathrm{kg} \mathrm{DMI} / \mathrm{kg}$ milk) & 1.38 & 1.40 & 1.44 & 1.54 & 13.606 & 0.432 \\
\hline
\end{tabular}

${ }^{1}$ Control - 100\% soybean meal and 0\% slow-release urea; 34SRU - 66\% soybean meal and 34\% slow-release urea; 66 SRU - 34\% soybean meal and 66\% slow-release urea; 100SRU - $0 \%$ soybean meal and $100 \%$ slow-release urea.

BW - body weight; DMI - dry matter intake; CV - coefficient of variation.

Table 4 - Mean values for apparent digestibility of dry matter, crude protein and neutral detergent fiber according to each treatment

\begin{tabular}{lccccrr}
\hline \multirow{2}{*}{ Apparent digestibility (\%) } & \multicolumn{3}{c}{ Treatments $^{1}$} & \multirow{2}{*}{ CV (\%) } & P-value \\
\cline { 2 - 5 } & Control & 34SRU & 66SRU & 100SRU & 4.213 \\
Dry matter & 57.78 & 59.77 & 57.35 & 57.74 & 0.235 \\
Crude protein & 57.50 & 59.31 & 57.48 & 60.26 & 4.428 & 0.123 \\
Neutral detergent fiber & 38.89 & 36.40 & 34.27 & 35.29 & 9.860 & 0.101 \\
\hline
\end{tabular}

${ }^{1}$ Control - 100\% soybean meal and $0 \%$ slow-release urea; 34SRU - 66\% soybean meal and 34\% slow-release urea; 66 SRU - 34\% soybean meal and $66 \%$ slow-release urea; 100SRU - $0 \%$ soybean meal and $100 \%$ slow-release urea.

$\mathrm{CV}$ - coefficient of variation.

Table 5 - Mean values for milk yield and composition according to each treatment

\begin{tabular}{lcccccc}
\hline \multirow{2}{*}{ Variable } & \multicolumn{3}{c}{ Treatments $^{1}$} & \multirow{2}{*}{ CV (\%) } & \multirow{2}{*}{ P-value } \\
\cline { 2 - 5 } & Control & 34SRU & 66SRU & 100SRU & 19.621 \\
4\%FCMY (kg/animal.day) & 13.39 & 13.88 & 13.44 & 12.05 & 0.744 \\
Fat $(\mathrm{g} / \mathrm{kg})$ & 37.6 & 37.1 & 38.4 & 38.3 & 19.326 \\
Protein $(\mathrm{g} / \mathrm{kg})$ & 32.4 & 32.3 & 32.8 & 31.6 & 8.598 & 0.055 \\
Total solids $(\mathrm{g} / \mathrm{kg})$ & 127.9 & 127.1 & 128.4 & 128.0 & 5.377 & 0.052 \\
Solids nonfat $(\mathrm{g} / \mathrm{kg})$ & 90.3 & 90.0 & 90.0 & 89.8 & 2.661 \\
\hline
\end{tabular}

${ }^{1}$ Control - 100\% soybean meal and $0 \%$ slow-release urea; 34SRU - 66\% soybean meal and 34\% slow-release urea; 66 SRU - 34\% soybean meal and $66 \%$ slow-release urea; 100SRU - $0 \%$ soybean meal and $100 \%$ slow-release urea.

$\mathrm{CV}$ - coefficient of variation; $4 \% \mathrm{FCMY}$ - 4\%-fat-corrected milk yield. 
total solids and solids nonfat of the milk (Table 5), which averaged $13.19 \mathrm{~kg} /$ animal day ${ }^{-1}, 3.78 \%, 3.23 \%, 12.79 \%$, and $9.00 \%$, respectively.

\section{Discussion}

The absence of effects on DMI can be explained by the fact that the diets were isoproteic, so it can be inferred that up to the level of inclusion utilized in the current study ( 0 , 140, 260, and $390 \mathrm{~g}$, for the control, 34SRU, 66SRU, and 100SRU treatments, respectively), slow-release urea has no effect on the palatability of the diet.

Microbial growth is related to intake, as it provides better use of the ingested feed. This assertion allows us to assume that in the present study the slow-release urea met the rumen microbial demand for nitrogen, and thus provided an adequate microbial multiplication, which was enough so that there was no depression in intake.

Some studies (Galo et al., 2003; Abreu, 2010; Sinclair et al., 2012; Castañeda-Serrano et al., 2013) have been conducted using slow-release urea in ruminant diets, and also did not report differences related to DMI. Most of these experiments utilized dairy cows and tested SRU inclusion levels in the diets with partial or total replacement of the conventional urea or protein concentrates, e.g., soybean. The mean value of $3.39 \%$ observed here for DM intake as a function of body weight was higher than the $2.62 \%$ observed by Abreu (2010), whereas Sinclair (2012) obtained a feed conversion of $1.49 \mathrm{~kg} \mathrm{DMI} / \mathrm{kg}$ milk, close to that observed in our study.

The lack of differences among treatments for the digestibility-related variables helps to explain the absence of variation in intake observed throughout the experiment (Table 3).

For Köster et al. (1996), feed intake and digestibility are known to be closely related, and they can be affected by the rumen availability of $\mathrm{N}$. The $\mathrm{N}$ supply in the rumen implies proper growth of the rumen microbiota, which, in turn, is responsible for the digestibility of feeds in the rumen. When the dietary digestibility is elevated, the feed passage rate is consequently increased, which causes a faster rumen emptying and thus results in increased intake.

The lack of differences among the treatments for the digestibility variables, especially the apparent digestibilities of DM and CP, may be related to the use of sorghum silage. Some sorghum varieties contain significant amounts of some phenolic compounds such as tannins, which may compromise the nutritional value of animal diets as they reduce the digestibility of the proteins and starch. Some structural proteins present in sorghum form crosslinks among molecules, which increase the rigidity of the protein structure of grains (Duodo et al., 2003; Belton et al., 2006), which may thus interfere negatively with the digestibility of the dry matter.

Castañeda-Serrano et al. (2013) also did not observe differences among treatments for the total digestibility of $\operatorname{DM}(65.0 \%)$ and $\mathrm{CP}(63.5 \%)$, whose values were higher than those obtained in the present study. Galo et al. (2003), on the other hand, observed an increase in the total digestibility of DM and CP when using slow-release urea in diets for lactating cows. Ribeiro et al. (2011) also reported an increase in the digestibility of $\mathrm{CP}$ for all treatments with the use of NPN as compared with the control treatment.

Regarding the digestibility of NDF, the results obtained in the present study are similar to those observed by some authors (Galo et al., 2003; Azevedo et al., 2008; Santos et al., 2011), who did not detect effects of treatments using slowrelease urea on the digestibility of NDF either.

The studied diets might have not affected milk yield due to the productive potential of the animals (average milkyield level). Thus, the lower requirement of these animals makes it possible to infer that the slow-release urea met the rumen-digestible protein requirements, and consequently allowed for an adequate microbial protein synthesis.

Some authors (Souza et al., 2010; Santos et al., 2011; Sinclair et al., 2012) have worked with high-milk-yield cows (above $30 \mathrm{~kg} /$ animal day ${ }^{-1}$ ) and did not observe any effects of the use of slow-release urea on milk yield. Among these authors, only Souza et al. (2010) observed a reduction of the percentage of fat and total solids in the milk when protected urea was utilized.

In contrast, Abreu (2010) worked with average-milkyield crossbred animals and observed no influence of the levels of slow-release urea on $3.5 \%$-fat-corrected milk yield or fat, protein, total solids, and solids nonfat contents, obtaining an average yield of $10.8 \mathrm{~kg} /$ animal day ${ }^{-1}$.

Increase in milk yield was reported in the experiment of Akay et al. (2004), with 122 cows in a commercial herd, in which soybean meal and urea were substituted, in the control diet, for slow-release urea, wheat bran, and ground corn. In this case, production increased from 37.9 to 41.6 $\mathrm{kg} /$ animal day ${ }^{-1}$ due to the use of slow-release urea.

Substituting soybean meal and canola meal for urea or slow-release urea in grass- and corn-based diets for dairy cows, Sinclair et al. (2012) obtained an average DMI of $22.5 \mathrm{~kg} /$ day, without significant differences. CastañedaSerrano et al. (2013) used slow-release urea, replacing conventional urea, together with sorghum silage in the supplementation of diets for rumen-cannulated beef steers 
and also did not find differences for the intakes of DM (11.12 kg/day), CP (1.38 kg/day) and NDF (4.04 kg/day).

In an experiment similar to the current study, Abreu (2010) utilized crossbred cows (Holstein $\times$ Zebu) and evaluated four levels of slow-release urea: 40, 80, 160, and $320 \mathrm{~g} /$ animal day ${ }^{-1}$, in sugarcane-based diets, and also observed no effect of the levels of urea on DM and NDF intakes. However, there was a linear increase in crude protein intake according to the supply of SRU.

Some studies report contrasting results. Ribeiro et al. (2011) observed an increase in hay dry matter intake, as well as increased total NDF and crude protein intakes using conventional urea and slow-release urea as sources of NPN, via ruminal infusion in beef cattle fed low-quality hay of Brachiaria humidicola $\mathrm{cv}$. Lanero.

Reductions of 0.89 and $0.80 \mathrm{~kg} /$ day in the DMI were observed, respectively, by Akay et al. (2004) and Santos et al. (2011), using slow-release urea in diets for high-yield cows fed corn silage as the main roughage. Santos et al. (2011) attributed the decrease in intake to the possible existence of a systemic mechanism that was suggested by Wilson et al. (1975), who observed that the intraruminal infusion of urea was as depressant to intake as the incorporation of urea to the diet.

\section{Conclusions}

The total substitution of soybean meal, source of true protein, for slow-release urea, source of non-protein nitrogen, in diets for dairy cows of medium milk yield potential can be practiced with no deleterious effects on dry matter intake and digestibility, milk yield, or milk composition.

\section{References}

Abreu, D. C. 2010. Ureia de liberação lenta em dietas para vacas leiteiras mestiças em pasto ou confinadas. Dissertação (M.Sc.). Universidade Federal de Viçosa, Viçosa, MG, Brasil.

Akay V.; Tikofsky, J.; Holtz, C. and Dawson, K. A. 2004. Optigen ${ }^{\circledR}$ 1200: Controlled release of non-protein nitrogen in the rumen. p.179-185. In: International Feed Industry Symposium. Alltech's 20th Annual Symposium: re-imagining the feed industry, Lexington, Kentucky, USA.

AOAC - Association of Official Analytical Chemistry. 1998. Official methods of analysis. 16th ed. AOAC International, Gaithersburg, MA.

Azevedo, E. B.; Patiño, H. O.; Silveira, A. L. F.; López, J.; Brüning, G. and Kozloski G. V. 2008. Incorporação de ureia encapsulada em suplementos proteicos fornecidos para novilhos alimentados com feno de baixa qualidade. Ciência Rural 38:1381-1387.

Belton, P. S.; Delgadillo, I.; Halford, N. G. and Shewry, P. R. 2006. Kafirin structure and functionality. Journal of Cereal Science 44:272-286.
Box, G. E. P. and Cox, D. R. 1964 An analysis of transformations. Journal of the Royal Statistical Society 26:211-252.

Castañeda-Serrano, R. D.; Ferriani-Branco, A.; Teixeira, S.; GarciaDiaz, T. and Diego-Sofiati, A. 2013. Urea de liberación lenta en dietas para bovinos productores de carne: digestibilidad, síntesis microbiana y cinética ruminal. Agrociencia 47:13-24.

Duodu, K. G.; Taylor, J. R. N.; Belton, P. S. and Hamaker, B. R. 2003 Factors affecting sorghum protein digestibility. Journal of Cereal Science 38:117-131.

Firkins, J. L. 1996. Maximizing microbial protein synthesis in the rumen. Journal of Nutrition 126:1347-1354.

Galo, E.; Emanuele, S. M.; Sniffen, C. J.; White, J. H. and Knapp, J. R. 2003. Effects of a polymer-coated urea product on nitrogen metabolism in lactating Holstein dairy cattle. Journal of Dairy Science 86:2154-2162.

Goering, H. K. and Van Soest, P. J. 1970. Forage fiber analysis. Agricultural handbook No. 379. U.S.D.A., Washington, D.C.

Köster, H. H.; Cochran, R. C.; Titgemeyer, E. C.; Vanzant, E. S.; Abdelgadir, I. and St-Jean, G. 1996. Effect of increasing degradable intake protein on intake and digestion of low-quality, tallgrass-prairie forage by beef cows. Journal of Animal Science 74:2473-2481

Lapierre, H. and Lobley, G. E. 2001. Nitrogen recycling in the ruminant: a review. Journal of Dairy Science 84:223-236.

Mood, A. M.; Graybill, F. A. and Boes, D. C. 1974. Introduction to the theory of statistics. 3rd ed. McGraw-Hill, Tokyo.

NRC - National Research Council. 2001. Nutrient requirements of dairy cattle. 7th ed. National Academy Press, Washington, D.C.

Ribeiro, S. S.; Vasconcelos, J. T.; Morais, M. G.; Itavo, C. B. C. F. and Franco, G. L. 2011. Effects of ruminal infusion of a slow-release polymer-coated urea or conventional urea on apparent nutrient digestibility, in situ degradability, and rumen parameters in cattle fed low-quality hay. Animal Feed Science and Technology 164:53-61.

Russel, J. B.; O’Connor, J. D.; Fox, D. G.; Van Soest, P. J. and Sniffen, C. J. 1992. A net carbohydrate and protein system for evaluating cattle diets. I. Ruminal fermentation. Journal of Animal Science 70:3551-3561.

Santos, J. F.; Dias Júnior, G. S.; Bitencourt, L. L.; Lopes, N. M.; Siécola Júnior, S; Silva, J. R. M.; Pereira, R. A. N. and Pereira, M. N. 2011. Resposta de vacas leiteiras à substituição parcial de farelo de soja por ureia encapsulada. Arquivo Brasileiro de Medicina Veterinária e Zootecnia 63:423-432.

Silva, J. F. C. and Leão, M. I. 1979. Fundamentos de nutrição dos ruminantes. Ceres, Piracicaba.

Sinclair, L. A.; Blake, C. W.; Griffin, P. and Jones, G. H. 2012. The partial replacement of soybean meal and rapeseed meal with feed grade urea or a slow-release urea and its effect on the performance, metabolism and digestibility in dairy cows. Animal 6:920-927.

Sklan, D.; Ashkenazi, R.; Braun, A.; Devorin, A. and Tabori, K. 1992. Fatty acids, calcium soaps of fatty acids, and cottonseeds fed to high yielding cows. Journal of Dairy Science 75:2463-2472.

Souza, V. L.; Almeida, R.; Silva, D. F. F.; Piekarski, P. R. B.; Jesus, C. P. and Pereira, M. N. 2010. Substituição parcial de farelo de soja por ureia protegida na produção e composição do leite. Arquivo Brasileiro de Medicina Veterinária e Zootecnia 62:1415-1422.

Tempelman, R. J. 2004. Experimental design and statistical methods for classical and bioequivalence hypothesis testing with an application to dairy nutrition studies. Journal of Animal Science 82:162-172.

Thiex, N. J.; Manson, H.; Anderson, S. and Persson, J. Á. 2002. Determination of crude protein in animal feed, forage, grain, and oilseeds by using block digestion with a copper catalyst and steam 
distillation into boric acid: collaborative study. Journal of AOAC International 85:309-317.

Thiex, N. J.; Anderson, S. and Gildemeister, B. 2003. Crude fat, hexanes extraction, in feed, cereal grain, and forage (Randall/ soxtec/submersion method): collaborative study. Journal of AOAC International 86:899-908.

Van Soest, P. J. 1963. Use of detergents in the analysis of fibrous foods. II. A rapid method for the determination of fibre and lignin. Journal of the Association of the Official Analytical Chemists 46:829-835.
Weiss, W. P.; Conrad, H. R. and St. Pierre, N. R. 1992. A theoretically based model for predicting total digestible nutrient values of forages and concentrates. Animal Feed Science and Technology 39:95-110.

Williams, C. H.; David, D. J. and Iismaa, O. 1962. The determination of chromic oxide in faeces samples by atomic absorption spectrophotometry. Journal of Agricultural Science 59:381-385.

Wilson, G.; Martz, F. A.; Campbell, J. R. and Becker, B. A. 1975. Evaluation of factors responsible for reduced voluntary intake urea diets for ruminants. Journal of Animal Science 41:1431-1437. 